\title{
Endo-sponge in management of anastomotic colorectal leaks: a systematic review and meta-analysis
}

\section{(ㄷ)(우우}

\section{Authors}

Banreet S. Dhindsa ${ }^{2}$, Yassin Naga ${ }^{3}$, Syed M. Saghir ${ }^{3}$, Sarav Gunjit Singh Daid ${ }^{4}$, Saurabh Chandan ${ }^{5}$, Harmeet Mashiana², Amaninder Dhaliwal ${ }^{6}$, Abhitej Sidhu ${ }^{7}$, Harlan Sayles ${ }^{8}$, Daryl Ramai ${ }^{9}$, Ishfaq Bhat ${ }^{2}$, Shailender Singh ${ }^{2}$, Stephanie McDonough ${ }^{1}$, Douglas G. Adler ${ }^{1}$

Institutions

1 Division of Gastroenterology and Hepatology, University of Utah School of Medicine, Salt Lake City, Utah, United States

2 Division of Gastroenterology and Hepatology, University of Nebraska Medical Center, Omaha Nebraska, United States

3 University of Nevada Las Vegas School of Medicine, Las Vegas, Nevada, United States

4 Metropolitan Hospital Center/New York Medical College, New York, New York, United States

5 Creighton University Medical Center, Omaha, Nebraska, United States

6 Division of Gastroenterology and Hepatology, Moffitt Cancer Center, Tampa, Florida, United States

7 Bharati Vidyapeeth University Medical College, Pune, Maharashtra, India

8 Department of Biostatistics, University of Nebraska Medical Center, Omaha, Nebraska, United States

9 Department of Internal Medicine, The Brooklyn Hospital Center, Brooklyn, New York, United States

submitted 5.1 .2021

accepted after revision 29.3.2021

\section{Bibliography}

Endosc Int Open 2021; 09: E1342-E1349

DOI 10.1055/a-1490-8783

ISSN 2364-3722

(c) 2021. The Author(s).

This is an open access article published by Thieme under the terms of the Creative Commons Attribution-NonDerivative-NonCommercial License, permitting copying and reproduction so long as the original work is given appropriate credit. Contents may not be used for commercial purposes, or adapted, remixed, transformed or built upon. (https://creativecommons.org/licenses/by-nc-nd/4.0/)

Georg Thieme Verlag KG, Rüdigerstraße 14,

70469 Stuttgart, Germany

\section{Corresponding author}

Douglas G. Adler, MD, FACG, AGAF, FASGE, Professor of Medicine, Director of Therapeutic endoscopy, Director, GI fellowship program, Gastroenterology and Hepatology, University of Utah School of Medicine, Huntsman Cancer
Center, 30 N 1900 E, Room 4R118, Salt Lake City, Utah 84132, United States

Fax: +1-801-581-8007

dougraham2001@gmail.com

Supplementary material is available under https://doi.org/10.1055/a-1490-8783

\section{ABSTRACT}

Background and study aims Following colorectal surgery, anastomotic dehiscence and leak formation has an incidence of $2 \%$ to $7 \%$. Endo-SPONGE has been applied in the management of anastomatic leaks (ALs) after colorectal surgery. This is the first systematic review and meta analysis to evaluate the efficacy and safety of Endo-SPONGE in the management of colorectal ALs.

Patients and methods The primary outcomes assessed were the technical and clinical success of Endo-SPONGE placement in colorectal ALs. The secondary outcomes assessed were the overall adverse events (AEs) and the $A E$ subtypes. Pooled estimates were calculated using randomeffects models with $95 \%$ confidence interval (C.I.). The statistical analysis was done using STATA v16.1 software (StataCorp, LLC College Station, Texas, United States).

Results The analysis included 17 independent cohort studies with a total of 384 patients. The rate of technical success was $99.86 \%\left(95 \% \mathrm{Cl}\right.$ : 99.2\%, $\left.100 \% ; P=0.00 ; I^{2}=70.69 \%\right)$ and the calculated pooled rate of clinical success was 84.99\% (95\% Cl: $\left.77.4 \%, 91.41 \% ; P=0.00 ; I^{2}=68.02 \%\right)$. The calculated pooled rate of adverse events was $7.6 \%(95 \% \mathrm{Cl}$ : $\left.3.99 \%, 12.21 \% ; P=0.03 ; I^{2}=42.5 \%\right)$ with recurrent abscess formation and bleeding being the most common AEs. Moderate to substantial heterogeneity was noted in our meta-analysis.

Conclusions Endoscopic vacuum therapy appears to be a minimally invasive, safe, and effective treatment modality for patients with a significant colorectal leak without any generalized peritonitis with high clinical and technical success rates and a low rate of adverse events. Further prospective or randomized controlled trials are needed to validate our findings. 


\section{Introduction}

Following colorectal surgery, anastomotic dehiscence and subsequent leak formation has an incidence of $2 \%$ to $7 \%$ [1-3]. Depending upon the location of the leak, the rate may be as high as $10 \%$ to $20 \%$ (coloanal) or as low as $1 \%$ to $3 \%$ (ileocolic). Anastomotic leaks (ALs) in colorectal surgery have been associated with an increase in mortality from $1.6 \%$ to $12 \%$ [4]. A study by Alves et al showed that the risk of AL increased with the presence of risk factors such as leukocytosis, increased duration of the surgical procedure, recent steroid use, the location of procedure (ileorectal vs colocolic), and renal failure, among others [4]. The goal of treating anastomotic leakage is the prevention of sepsis and chronic fistula formation [5].

The management of ALs is not standardized [6]. The patient's clinical condition is the major determining factor for management. Patients with sepsis and signs of peritonitis generally undergo surgery while stable patients can be considered for endoscopic therapy [7]. Various endoscopic treatments have evolved for the management of $\mathrm{AL}$ in colorectal surgery and these include endoscopic self-expanding metal stents (SEMS), endoscopic clips, and endoscopic vacuum-assisted closure devices [8]. Smaller leaks are usually managed with stents or clips while endoscopic vacuum therapy (EVT) is preferred for larger leaks $(>2 \mathrm{~cm}$ ) or for leaks with an associated abscess.

EVT was first described by Weidenhagen et al. in 2008 to treat patients with presacral abscesses [9]. Since then, it has been successfully applied in the management of ALs after colorectal surgery. In this technique, the cavity and the size of the leak are determined via direct endoscopic examination. A sponge is shaped to fit the size of the cavity/leak and inserted endoscopically through an overtube. This sponge is connected to a drainage tube which is in turn connected to vacuum suction device to continuously remove secretions. The sponge is exchanged every few days for a smaller replacement, to fit the diminishing cavity, until healing is complete. The applied negative pressure also improves microcirculation, and induces granulation formation in the area of the defect helping in the closure of the pelvic cavity [10]. The most commonly used commercially available EVT system is Endo-SPONGE System (B. Braun, Meslungen, Germany).

Our meta-analysis aims to evaluate the efficacy and safety of Endo-SPONGE System in the management of colorectal leaks.

\section{Methods}

\section{Search strategy}

We reviewed literature from several databases such as PubMed, EMBASE, CINAHL, Cochrane and Google Scholar (from inception to July 2020). We utilized several combinations of keywords in our literature search such as: 'colorectal,' 'endoscopic,' 'leak,' 'anastomosis,' 'vacuum' and 'endosponge'. We had two authors (BD and SS) carry out the search and review the articles individually. If there were any discrepancies, then a third author (SD) would review for resolution. The references section of each selected article was reviewed for additional articles. Any article that did not meet the inclusion criteria was excluded. The preferred reporting items for systematic reviews and meta-analyses (PRISMA) guidelines were utilized to identify studies reporting outcomes on Endo-SPONGE for colorectal anastomotic leaks [11]. Refer to Supplementary Fig. 1.

\section{Study selection}

We reviewed studies evaluating the efficacy and safety of EndoSPONGE for colorectal anastomotic leaks. Any study that met our inclusion criteria and had data to be extracted was included in our final analysis. The inclusion criteria was studies reporting technical success, clinical success and adverse events of endosponge in colorectal leaks. The following exclusion criteria were used: (1) studies utilizing other endoscopic methods to repair anastomotic leaks, (2) individuals age $<18$, (3) sample size $<10$ patients, and (4) studies not in English language. If overlapping cohorts were encountered, then the most appropriate study would be selected and the others were excluded.

\section{Data abstraction and quality assessment}

The selected articles were independently assessed for quality by two authors (BD and SS). The quality of the studies was ascertained by the Newcastle-Ottawa scale [12]. Refer to Supplementary Table 1.

\section{Outcomes assessed}

The primary outcomes assessed were the technical and clinical success of Endo-SPONGE placement in colorectal anastomotic leaks.

The secondary outcomes assessed were the overall adverse events and the adverse event subtypes.

\section{Definitions}

Technical success was defined as successful placement of the Endo-SPONGE in the cavity in 13 of 17 studies $[5,6,10,13-$ $22]$. Clinical success was defined as closure of the anastomotic leak, confirmed via endoscopy or contrast enhanced computed tomography imaging $[5,6,10,13,14,17,19,21-24]$. Adverse events (AEs) were related directly to the procedure.

\section{Statistical analysis}

A random effects model was used to calculate the pooled estimates for each outcome of interest as suggested by the metaanalysis techniques by DerSimonian and Laird [25]. A continuity correction of 0.5 would be added prior to statistical analysis if zero's occurred in the incidence of an outcome of a study [26]. We utilized the Cochran Q statistical test and 12 statistics to assess heterogeneity $[27,28]$. Low, moderate, substantial or considerable heterogeneity was classified by the values of $<30 \%$, $30 \%$ to $60 \%, 61 \%$ to $75 \%$, and $>75 \%$, respectively [29]. To determine if publication bias was present, we qualitatively ascertained by direct visualization of the funnel plot [30]. All analyses were performed using STATA v16.1 software (StataCorp, LLC College Station, Texas, United States). 
- Table 1 Characteristics of the included studies.

\begin{tabular}{|c|c|c|c|c|c|c|c|c|c|c|}
\hline Study & Year & Country & $\begin{array}{l}\text { Type of } \\
\text { study }\end{array}$ & $\begin{array}{l}\text { Single/ } \\
\text { multi- } \\
\text { center }\end{array}$ & $\begin{array}{l}\text { Manuscript/ } \\
\text { abstract }\end{array}$ & $\begin{array}{l}\text { No. of } \\
\text { patients }\end{array}$ & $\begin{array}{l}\text { No. of } \\
\text { proce- } \\
\text { dures }\end{array}$ & $\begin{array}{l}\text { Mean } \\
\text { age }\end{array}$ & Males & $\begin{array}{l}\text { Fe- } \\
\text { males }\end{array}$ \\
\hline Wasmann [22] & 2019 & Austria & $\begin{array}{l}\text { Retro- } \\
\text { spective }\end{array}$ & Single & Manuscript & 18 & 57 & 40.56 & 12 & 6 \\
\hline $\begin{array}{l}\text { Van Koperen } \\
{[21]}\end{array}$ & 2008 & France & $\begin{array}{l}\text { Retro- } \\
\text { spective }\end{array}$ & $\begin{array}{l}\text { Multi- } \\
\text { center }\end{array}$ & Manuscript & 16 & 208 & 64 & 9 & 7 \\
\hline Keskin [17] & 2015 & $\begin{array}{l}\text { Nether- } \\
\text { lands }\end{array}$ & $\begin{array}{l}\text { Retro- } \\
\text { spective }\end{array}$ & Single & Manuscript & 15 & 33 & 55 & 8 & 7 \\
\hline $\begin{array}{l}\text { Jimenez- } \\
\text { Rodriguez [16] }\end{array}$ & 2018 & $\begin{array}{l}\text { Nether- } \\
\text { lands }\end{array}$ & $\begin{array}{l}\text { Retro- } \\
\text { spective }\end{array}$ & Single & Manuscript & 22 & 69 & 64.8 & 18 & 4 \\
\hline Grande [34] & 2020 & $\begin{array}{l}\text { Nether- } \\
\text { lands }\end{array}$ & $\begin{array}{l}\text { Retro- } \\
\text { spective }\end{array}$ & Single & Abstract & 40 & 320 & - & 31 & 9 \\
\hline Glitsch [14] & 2008 & Spain & $\begin{array}{l}\text { Retro- } \\
\text { spective }\end{array}$ & Single & manuscript & 17 & 161 & 61.1 & 14 & 3 \\
\hline $\begin{array}{l}\text { Gardenbroek } \\
\text { [5] }\end{array}$ & 2014 & $\begin{array}{l}\text { Spain/ } \\
\text { USA }\end{array}$ & $\begin{array}{l}\text { Retro- } \\
\text { spective }\end{array}$ & Single & Manuscript & 15 & 45 & 37 & 12 & 3 \\
\hline Arezzo [13] & 2015 & Turkey & $\begin{array}{l}\text { Retro- } \\
\text { spective }\end{array}$ & Single & Manuscript & 14 & 228 & 68 & 7 & 7 \\
\hline Abdalla [6] & 2020 & France & $\begin{array}{l}\text { Retro- } \\
\text { spective }\end{array}$ & $\begin{array}{l}\text { Multi- } \\
\text { center }\end{array}$ & Manuscript & 47 & 310 & 64.7 & 36 & 11 \\
\hline Strangio [10] & 2015 & Germany & $\begin{array}{l}\text { Prospec- } \\
\text { tive }\end{array}$ & Single & Manuscript & 25 & 225 & 67 & 18 & 7 \\
\hline Riss [36] & 2010 & Austria & $\begin{array}{l}\text { Retro- } \\
\text { spective }\end{array}$ & $\begin{array}{l}\text { Multi- } \\
\text { center }\end{array}$ & Manuscript & 20 & - & 66.3 & 13 & 7 \\
\hline Nerup [20] & 2013 & Denmark & $\begin{array}{l}\text { Retro- } \\
\text { spective }\end{array}$ & $\begin{array}{l}\text { Multi- } \\
\text { center }\end{array}$ & Manuscript & 13 & 104 & 64 & 11 & 2 \\
\hline Mussetto [19] & 2017 & Italy & $\begin{array}{l}\text { Retro- } \\
\text { spective }\end{array}$ & Single & Manuscript & 11 & 176 & 71 & 6 & 5 \\
\hline $\begin{array}{l}\text { Mansilla-Vivar } \\
\text { [6] }\end{array}$ & 2020 & Spain & $\begin{array}{l}\text { Prospec- } \\
\text { tive }\end{array}$ & $\begin{array}{l}\text { Multi- } \\
\text { center }\end{array}$ & Abstract & 20 & - & 70 & 17 & 3 \\
\hline Lisi [24] & 2017 & Italy & $\begin{array}{l}\text { Prospec- } \\
\text { tive }\end{array}$ & Single & Abstract & 14 & - & - & - & - \\
\hline $\begin{array}{l}\text { Kuhn + Zimmer- } \\
\text { man [18] }\end{array}$ & 2020 & Germany & $\begin{array}{l}\text { Retro- } \\
\text { spective }\end{array}$ & Single & Manuscript & 56 & 448 & 66 & 34 & 22 \\
\hline $\begin{array}{l}\text { Kuhn + Janisch } \\
{[23]}\end{array}$ & 2020 & Germany & $\begin{array}{l}\text { Retro- } \\
\text { spective }\end{array}$ & Single & Manuscript & 21 & - & 64.9 & 16 & 5 \\
\hline
\end{tabular}

\section{Results}

\section{Search results and population characteristics}

From an initial group of 655 studies, 17 studies reported data regarding the use of Endo-SPONGE in 384 patients with colorectal leaks. Studies with overlapping cohorts were identified and the most appropriate ones were included in final analysis. The majority of the patients were males $(68.22 \%$ reported in 16 studies) and the mean age was 61.62 (range 37-71) years. Four cases were secondary to traumatic perforation and the remainder were anastomotic leaks.
Average time to detection of leaks was 28.08 (range 7.1-85) days from surgery (reported in $9 / 17$ studies) and average length of therapy was 33.1 (range 15-108) days. The average number of procedures was 8.23 (range $2.2-16.2$ ) and the average follow-up was 18.2 (range 2-48) months. P Table 1 describes the characteristics of the included studies. The schematic diagram of study selection is shown in Supplementary Fig. 1. 


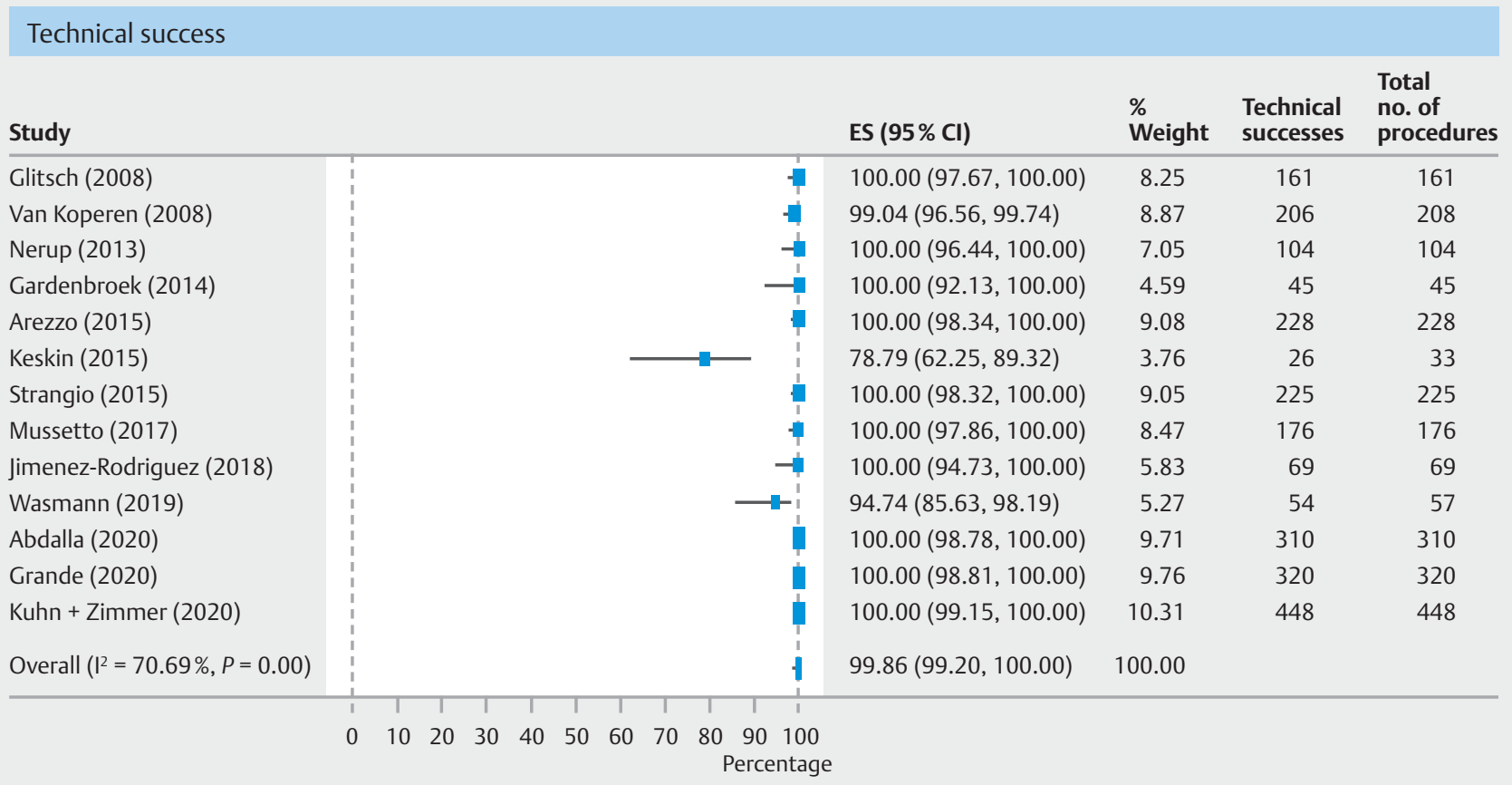

Fig. 1 Forest plot showing technical success with Endo-SPONGE for colorectal leaks.

\section{Clinical success}

\begin{tabular}{|c|c|c|c|c|c|}
\hline Study & & $\mathrm{ES}(95 \% \mathrm{Cl})$ & $\begin{array}{l}\% \\
\text { Weight }\end{array}$ & $\begin{array}{l}\text { Technical } \\
\text { successes }\end{array}$ & $\begin{array}{l}\text { Total } \\
\text { no. of } \\
\text { patients }\end{array}$ \\
\hline Glitsch (2008) & $\longrightarrow$ & $94.12(73.02,98.95)$ & 5.60 & 16 & 17 \\
\hline Van Koperen (2008) & $\longrightarrow$ & $56.25(33.18,76.90)$ & 5.47 & 9 & 16 \\
\hline Riss (2010) & 1 & $75.00(53.13,88.81)$ & 5.93 & 15 & 20 \\
\hline Nerup (2013) & 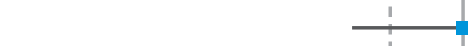 & $100.00(77.19,100.00)$ & 5.04 & 13 & 13 \\
\hline Gardenbroek (2014) & & $93.33(70.18,98.81)$ & 5.34 & 14 & 15 \\
\hline Arezzo (2015) & & $78.57(52.41,92.43)$ & 5.19 & 11 & 14 \\
\hline Keskin (2015) & & $80.00(54.81,92.95)$ & 5.34 & 12 & 15 \\
\hline Strangio (2015) & - & $88.00(70.04,95.93)$ & 6.36 & 22 & 25 \\
\hline Lisi (2017) & & $100.00(78.47,100.00)$ & 5.19 & 14 & 14 \\
\hline Mussetto (2017) & - & $90.91(62.26,98.38)$ & 4.68 & 10 & 11 \\
\hline Jimenez-Rodriguez (2018) & - & $90.91(72.19,97.47)$ & 6.11 & 20 & 22 \\
\hline Wasmann (2019) & & $94.44(74.24,99.01)$ & 5.72 & 17 & 18 \\
\hline Abdalla (2020) & $\longrightarrow$ & $55.32(41.25,68.59)$ & 7.36 & 26 & 47 \\
\hline Grande (2020) & & $85.00(70.93,92.94)$ & 7.13 & 34 & 40 \\
\hline Kuhn + Janish (2020) & & $95.24(77.33,99.15)$ & 6.02 & 20 & 21 \\
\hline Kuhn + Zimmer (2020) & & $83.93(72.19,91.31)$ & 7.58 & 47 & 56 \\
\hline Mansilla-Vivar (2020) & $\longrightarrow$ & $55.00(34.21,74.18)$ & 5.93 & 11 & 20 \\
\hline Overall $\left(I^{2}=68.02 \%, P=0.00\right)$ & & $84.99(77.40,91.41)$ & 100.00 & & \\
\hline
\end{tabular}

Fig. 2 Forest plot showing clinical success with Endo-SPONGE for colorectal leaks. 
- Table2 Adverse events with the Endo-SPONGE.

\begin{tabular}{|c|c|c|c|c|c|c|c|c|c|}
\hline Study & Year & $\begin{array}{l}\text { Total } \\
\text { adverse } \\
\text { events }\end{array}$ & $\begin{array}{l}\text { Bleed- } \\
\text { ing }\end{array}$ & $\begin{array}{l}\text { Perfora- } \\
\text { tion }\end{array}$ & Pain & $\begin{array}{l}\text { Stent mi- } \\
\text { gration }\end{array}$ & Abscess & $\begin{array}{l}\text { Reste- } \\
\text { nosis }\end{array}$ & Others \\
\hline Wasmann [22] & 2019 & 2 & 0 & 0 & 0 & 0 & 1 & 0 & 1 \\
\hline Van Koperen [21] & 2008 & 5 & 1 & 0 & 1 & 0 & 2 & 0 & 1 \\
\hline Keskin [17] & 2015 & 3 & 1 & 0 & 0 & 0 & 0 & 0 & 2 \\
\hline Jimenez- Rodriguez [16] & 2018 & 1 & 0 & 0 & 0 & 0 & 0 & 1 & 0 \\
\hline Grande [34] & 2020 & 2 & 1 & 0 & 0 & 0 & 0 & 0 & 1 \\
\hline Glitsch [14] & 2008 & 2 & 0 & 0 & 0 & 0 & 0 & 0 & 2 \\
\hline Gardenbroek [5] & 2014 & 1 & 0 & 0 & 0 & 0 & 0 & 0 & 1 \\
\hline Arezzo [13] & 2015 & 1 & 0 & 0 & 0 & 0 & 1 & 0 & 0 \\
\hline Abdalla [6] & 2020 & 2 & 0 & 0 & 0 & 0 & 2 & 0 & 0 \\
\hline Strangio [10] & 2015 & 3 & 0 & 0 & 0 & 0 & 1 & 0 & 2 \\
\hline Riss [36] & 2010 & 1 & 0 & 0 & 0 & 0 & 0 & 1 & 0 \\
\hline Nerup [20] & 2013 & 1 & 0 & 0 & 0 & 0 & 0 & 1 & 0 \\
\hline Mussetto [19] & 2017 & 2 & 0 & 0 & 0 & 0 & 0 & 2 & 0 \\
\hline Mansilla-Vivar [6] & 2020 & 0 & 0 & 0 & 0 & 0 & 0 & 0 & 0 \\
\hline Lisi [24] & 2017 & 5 & 0 & 0 & 5 & 0 & 0 & 0 & 0 \\
\hline Kuhn + Zimmerman [18] & 2020 & 2 & 2 & 0 & 0 & 0 & 0 & 0 & 0 \\
\hline Kuhn + Janisch [23] & 2020 & 0 & 0 & 0 & 0 & 0 & 0 & 0 & 0 \\
\hline
\end{tabular}

\section{Characteristics and quality of included studies}

The analysis included 17 independent cohort studies with a total of 384 patients. There were five multicenter studies, no population-based and 12 single-center studies included in our final analysis. Three studies had more than 30 patients, five studies had more than 20 patients, and nine studies had more than 10 patients. Fourteen studies were published in manuscript form and three studies were published in abstract form. $>$ Table 1 describes the characteristics of the included studies.

Quality assessment was performed with the help of the NOS scale. Nine studies were of good quality and eleven study were of fair quality. No poor quality studies were found. Details of quality assessment can be seen in Supplementary Table 1.

\section{Meta-analysis outcomes}

Primary outcomes

The rate of technical success was $99.86 \%$ (95\% Cl: $99.20 \%$, $\left.100.00 \% ; I^{2}=70.69 \%\right)$ and the calculated pooled rate of clinical success was $84.99 \%$ (95\% Cl: $77.40 \%, 91.41 \%$; $\mathrm{I}^{2}=68.02 \%$ ).

-Fig. 1 and > Fig. 2 shows the Forest Plots for technical and clinical successes of Endo-SPONGE in colorectal leaks.

\section{Secondary outcomes}

The calculated pooled rate of AEs was $7.69 \%$ (95\% Cl: $3.99 \%$, $12.21 \% ; I^{2}=42.5 \%$ ) with recurrent abscess formation and bleeding being the most common AEs. > Fig. 3 shows the Forest Plots for total adverse events of Endo-SPONGE in colorectal leaks. As per American Society of Gastrointestinal Endoscopy criteria, $60.06 \%$ of the AEs were mild and $36.36 \%$ were moderate [31]. > Table 2 describes the AEs in different studies.

\section{Validation of meta-analysis results}

\section{Sensitivity analysis}

To assess whether any one study had a dominant effect on the meta-analysis, we excluded one study at a time and analyzed its effect on the main summary estimate. Based on this analysis, no single study significantly affected the outcome or the heterogeneity.

\section{Heterogeneity}

Based on Q statistics, and 12 analysis for heterogeneity, substantial heterogeneity was noted in the analysis of technical and clinical success of Endo-SPONGE and moderate heterogeneity was seen for total AEs. 
Total adverse effects

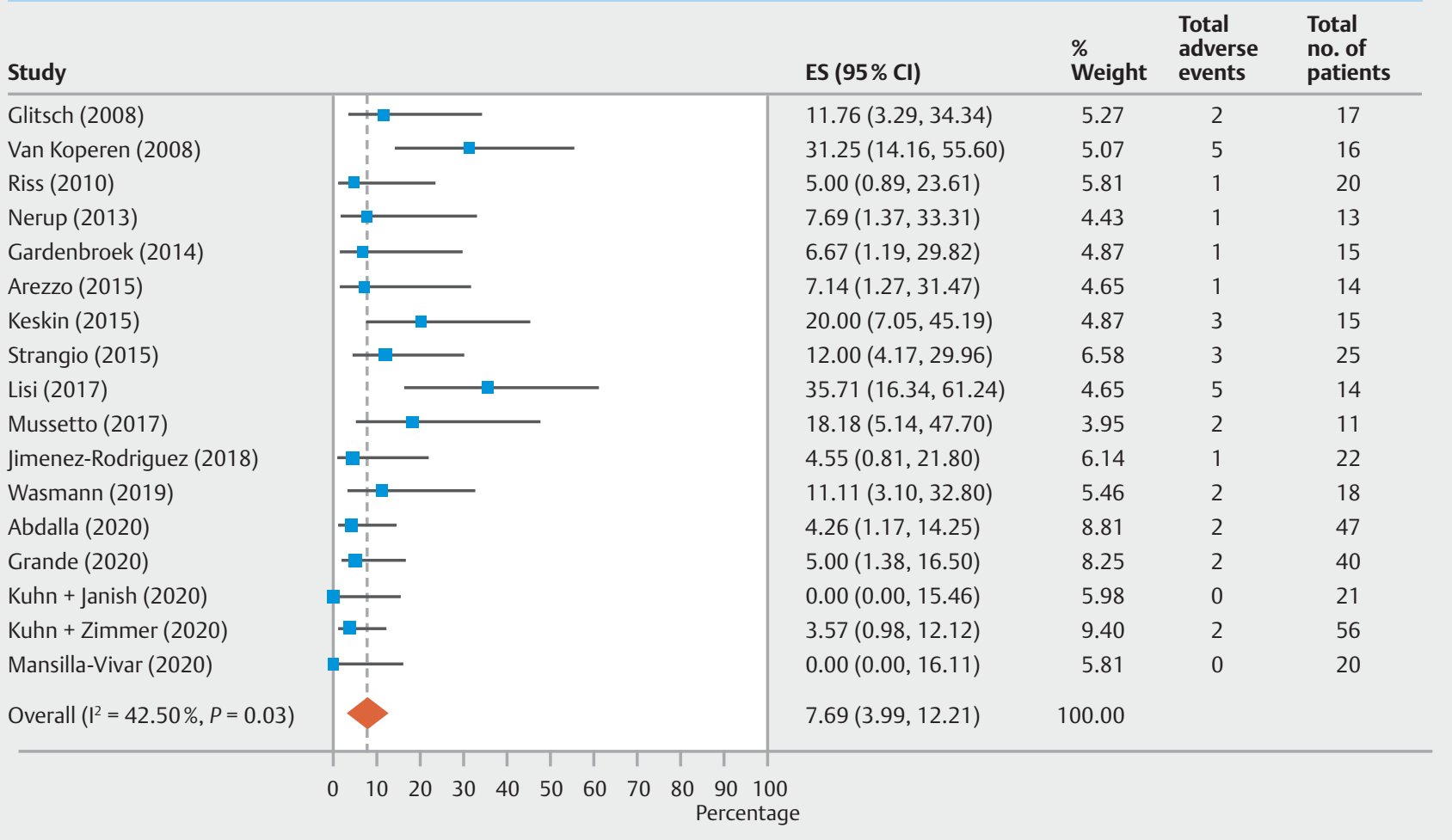

- Fig. 3 Forest plot showing total adverse events with Endo-SPONGE for colorectal leaks.

\section{Publication bias}

Assessment of publication bias was difficult due to the small size of the majority of studies. These studies are one-arm with dichotomous outcomes.

\section{Discussion}

Our study is the first meta-analysis that demonstrates that EVT is a minimally invasive treatment option for management of colorectal ALs. This meta-analysis shows that EVT has a high technical and clinical success rate with a low rate of AEs.

The technical success of EVT in our meta-analysis was $99.86 \%$ while the clinical success rate was also high at $84.99 \%$. The overall success of EVT is increased when it is used as an early intervention $[6,13,16,17,21]$. In the study by Abdalla et al, early endoluminal therapy (within 15 days) showed a higher clinical success rate when compared to late endoluminal therapy performed after 15 days ( $72.4 \%$ vs $27.8 \%$ ) [6]. The poor outcomes seen with delayed intervention were largely attributed to the development of fibrosis of the neorectum, which impairs healing and closure [6]. Abdalla et al also reported that the use of EVT as the primary treatment for colorectal ALs had a significantly higher success rate than salvage EVT in patients who underwent prior surgical procedures. (73\% vs $33 \%$ ) [6]. In the study by Kuhn et al, the use of EVT in the treatment of rectal stump leakage following Hartmann's procedure also demonstrated a high clinical success rate (84\%) [18]. EVT was directly compared to conventional therapy including drainage, stoma diversion, or surgical revision in the study by Kuhn et al, which showed that patients who underwent EVT had significantly higher success rates compared to those who underwent conventional therapy and demonstrated significantly higher rates of stoma reversal [23].

Preoperative neoadjuvant chemoradiotherapy affected EVT treatment duration and success. In a study by Bernstorff et al, chemoradiation therapy was associated with larger cavity sizes, longer treatment durations, and a higher number of sponge exchanges [32]. However, most patients were ultimately successfully treated and avoided additional surgery [32]. Conversely, in the study by Kuhn et al, preoperative chemoradiation therapy was a significant predictor of EVT treatment failure [18]. This can be potentially attributed tissue atrophy, fibrosis, and vascular damage associated with chemoradiation therapy [33]. Patient comorbidities and patient counselling should be taken into consideration in the decision making to undergo EVT in the setting of preoperative radiochemotherapy [33]. In one study, EVT was shown to preserve bowel continuity through ileostomy reversal in $86.7 \%$ of patients as compared to $37.5 \%$ among patients undergoing conservative treatment [23].

EVT appears to be a safe procedure with a low rate of AEs. The overall $A E$ rate observed in our meta-analysis was $7.6 \%$ with only a few cases of bleeding $(0.35 \%)$ and no cases of perforation. The rate of recurrent abscess formation was also very low $(0.52 \%)$. No procedure-related deaths were observed. The 
rate of anastomotic stenosis was very low (0.14\%) and these strictures can be treated in some cases with balloon dilation, avoiding surgical intervention [16].

This meta-analysis has several limitations. The retrospective study design in most studies, small sample sizes, and the lack of any randomized controlled studies is a major limitation. There was moderate to substantial heterogeneity noted in our analysis. There were also no direct comparisons to other treatment modalities in colorectal ALs in most studies. In addition, there are no standardized criteria for treatment success in EVT, so data presented must be viewed with caution [6].

\section{Conclusions}

EVT appears to be a minimally invasive, safe, and effective treatment for patients with significant colorectal ALs with no generalized peritonitis. EVT has been shown to have high clinical and technical success rates with a low rate of AEs. Early intervention is the most important predictor of overall success. EVT also appears to increase the ability to maintain bowel continuity with increased rates of ileostomy reversal. Long-term randomized controlled trials and direct comparison studies are needed to further evaluate success of this procedure.

Competing interests

The authors declare that they have no conflicts of interest.

\section{References}

[1] Hyman N, Manchester TL, Osler T et al. Anastomotic leaks after intestinal anastomosis: it's later than you think. Annals of surgery 2007; 245: 254-258

[2] Kingham TP, Pachter HL. Colonic anastomotic leak: risk factors, diagnosis, and treatment. J Am Coll Surg 2009; 208: 269-278

[3] Slieker JC, Komen N, Mannaerts GH et al. Long-term and perioperative corticosteroids in anastomotic leakage: a prospective study of 259 left-sided colorectal anastomoses. Arch Surg 2012; 147: 447-452

[4] Alves A, Panis Y, Trancart D et al. Factors associated with clinically significant anastomotic leakage after large bowel resection: multivariate analysis of 707 patients. World J Surg 2002; 26: 499-502

[5] Gardenbroek T], Musters GD, Buskens C] et al. Early reconstruction of the leaking ileal pouch-anal anastomosis: a novel solution to an old problem. Colorectal Dis 2015; 17: 426-432

[6] Abdalla S, Cotte E, Epin A et al. Short-term and long-term outcome of endoluminal vacuum therapy for colorectal or coloanal anastomotic leakage: results of a nationwide multicenter cohort study from the French GRECCAR Group. Dis Colon Rectum 2020; 63: 371-380

[7] Thomas MS, Margolin DA. Management of colorectal anastomotic leak. Clin Colon Rectal Surg 2016; 29: 138-144

[8] Sevim Y, Celik SU, Yavarifar H et al. Minimally invasive management of anastomotic leaks in colorectal surgery. World J Gastrointest Surg 2016; 8: 621-626

[9] Weidenhagen R, Gruetzner KU, Wiecken T et al. Endoscopic vacuumassisted closure of anastomotic leakage following anterior resection of the rectum: a new method. Surg Endosc 2008; 22: 1818-1825
[10] Strangio G, Zullo A, Ferrara EC et al. Endo-sponge therapy for management of anastomotic leakages after colorectal surgery: A case series and review of literature. Dig Liver Dis 2015; 47: 465-469

[11] Moher D, Liberati A, Tetzlaff J et al. Preferred reporting items for systematic reviews and meta-analyses: the PRISMA statement. Ann Intern Med 2009; 151: 264-269

[12] Stang A. Critical evaluation of the Newcastle-Ottawa scale for the assessment of the quality of nonrandomized studies in meta-analyses. Eur J Epidemiol 2010; 25: 603-605

[13] Arezzo A, Verra M, Passera R et al. Long-term efficacy of endoscopic vacuum therapy for the treatment of colorectal anastomotic leaks. Dig Liver Dis 2015; 47: 342-345

[14] Glitsch A, von Bernstorff W, Seltrecht U et al. Endoscopic transanal vacuum-assisted rectal drainage (ETVARD): an optimized therapy for major leaks from extraperitoneal rectal anastomoses. Endoscopy 2008; 40: 192-199

[15] Grande G, Caruso A, Bertani H et al. EVAC therapy for rectal anastomotic leaks and perforation. Endoscopy 2020; 52: OP297

[16] Jimenez-Rodriguez RM, Araujo-Miguez A, Sobrino-Rodriguez $S$ et al. A New perspective on vacuum-assisted closure for the treatment of anastomotic leak following low anterior resection for rectal cancer, is it worthy? Surg Innov 2018; 25: 350-356

[17] Keskin M, Bayram O, Bulut T et al. Effectiveness of Endoluminal vacuum-assisted closure therapy (Endosponge) for the treatment of pelvic anastomotic leakage after colorectal surgery. Surg Laparosc Endosc Percutan Tech 2015; 25: 505-508

[18] Kuhn F, Zimmermann J, Beger $N$ et al. Endoscopic vacuum therapy for treatment of rectal stump leakage. Surg Endosc 2021; 35: 1749-1754

[19] Mussetto A, Arena R, Buzzi A et al. Long-term efficacy of vacuum-assisted therapy (Endo-SPONGE ${ }^{\circledR}$ ) in large anastomotic leakages following anterior rectal resection. Ann Gastroenterol 2017; 30: 649653

[20] Nerup N, Johansen JL, Alkhefagie GA et al. Promising results after endoscopic vacuum treatment of anastomotic leakage following resection of rectal cancer with ileostomy. Danish Med J 2013; 60: A4604

[21] van Koperen PJ, van Berge Henegouwen MI, Rosman C et al. The Dutch multicenter experience of the endo-sponge treatment for anastomotic leakage after colorectal surgery. Surg Endosc 2009; 23: 1379-1383

[22] Wasmann KA, Reijntjes MA, Stellingwerf ME et al. Endo-sponge Assisted early surgical closure of ileal pouch-anal anastomotic leakage preserves long-term function: a cohort study. J Crohns Colitis 2019; 13: $1537-1545$

[23] Kuhn F, Janisch F, Schwandner F et al. Comparison Between endoscopic vacuum therapy and conventional treatment for leakage after rectal resection. World J Surg 2020; 44: 1277-1282

[24] Lisi G, Milito G. Our experience with Endo-Sponge: conservative treatment of an anastomotic leak. In: Tech Coloproctol 21 (2017). 6th Educational Meeting "Colorectal Cancer". Tech Coloproctol 2017; 21: 79-89

[25] DerSimonian R, Laird N. Meta-analysis in clinical trials. Control Clin Trials 1986; 7: 177-188

[26] Sutton AJ, Abrams KR, Jones DR et al. Methods for meta-analysis in medical research. Chichester: Wiley; 2000

[27] Higgins JP, Thompson SG, Deeks J] et al. Measuring inconsistency in meta-analyses. BMJ 2003; 327: 557-560

[28] Kanwal F, White D. "Systematic Reviews and Meta-analyses" in Clinical Gastroenterology and Hepatology. Clin Gastroenterol Hepatol 2012; 10: 1184-1186

[29] Guyatt GH, Oxman AD, Kunz R et al. GRADE guidelines: 7. Rating the quality of evidence-inconsistency. | Clin Epidemiol 2011; 64: 12941302 
[30] Easterbrook P], Gopalan R, Berlin JA et al. Publication bias in clinical research. The Lancet 1991; 337: 867-872

[31] Cotton PB, Eisen GM, Aabakken L et al. A lexicon for endoscopic adverse events: report of an ASGE workshop. Gastrointest Endosc 2010; 71: 446-454

[32] von Bernstorff W, Glitsch A, Schreiber A et al. ETVARD (endoscopic transanal vacuum-assisted rectal drainage) leads to complete but delayed closure of extraperitoneal rectal anastomotic leakage cavities following neoadjuvant radiochemotherapy. Int J Colorectal Dis 2009; 24: $819-825$

[33] Mahendran B, Rossi B, Coleman M et al. The use of Endo-SPONGE((R)) in rectal anastomotic leaks: a systematic review. Tech Coloproctol 2020; 24: 685-694
[34] Grande G, Bertani H, Caruso A et al. Mo1783 EVAC Therapy for rectal anastomotic leaks and perforation. Gastrointest Endosc 2020; 91 : AB497

[35] Mansilla-Vivar R, Lovera M, Bustamante-Balén M et al. Endoscopic vacuum therapy (EVT) for treatment of anastomotic dehiscence after colorectal surgery: Prospective multicenter study. Digest Endosc 2020; 32: 7-16

[36] Riss S, Stift A, Kienbacher $C$ et al. Recurrent abscess after primary successful endo-sponge treatment of anastomotic leakage following rectal surgery. World J Gastroenterol 2010; 16: 4570-4574 